\title{
The Transference of the Language of Verse
}

\author{
Presented by:
}

Abdelnasser Mohammed Ahmed Abdallah Albogdady

Translating the language of verse is a challenge for the translator as he should live and put his mind in a poetical state. The translator of verse should sway with the different poetical images in order to be a carrying vessel for other cultures. Hence, liberating oneself from the narrow-minded feelings is the great obstacle that hinders the translator of poetry due to the fact that he should be in a state of empathy with the poet's personality alongside reading a great deal of the poet's other works for the sake of getting closer to his intellectual realm. Thus, translating poetry is believed to be next to impossible specially when trying to preserve both the form and content at the linguistic and cultural levels. To produce the exact purpose of poetry in another language, certainly, there should be some modifications in order to achieve the same aesthetic value of the original poem which is the measurement of success in poetry translating. Although there are many functions for poetry such as the informative, didactic, cognitive, practical and entertainment, the aesthetic function is the most noticeable and important one. To translate poetry, you are lying between the devil and the deep blue sea. Consequently, modification is a sore need, but it is a twosided coin because adding or losing any part of a poem leads to truncated images.

This paper is dedicated to study the language of verse in Shakespeare's Hamlet and the analysis of the means by which form and content are transferred into the Arabic versions of the English play by Jabra Ibrahim Jabra, Mohammed Awad Mohammed, and Mohammed Mohammed Enani. It is intended to show that poetry transference is not an easy task. Thus, this paper aims at discussing the process of translating poetry, breaks the myth of the untranslatability of poetry, and argues from the appropriate understanding of translation about the various functions of poetry. This paper attempts a comparative analysis of the approaches adopted by the three translators to transfer rhyme and rhythm. It also suggests, with examples taken from the three selected Arabic versions, how the translators under study, with their strategies, managed to open up another channel for human communication, as to understand one another better.

\section{1 -The form and content:}

The controversial debate of the supremacy of form over content and vice versa is an important issue in this discussion. The form or the style is a result of the motivated choices made by text producers who seek to provide specific stylistic effects in a specific language system and therefore in a specific setting. In this sense, the translator should be aware of this semiotic value of these stylistic effects. According to The Penguin Dictionary of Literary Terms and Literary Theory, style means "The characteristic manner of expression in Prose or verse; how a particular writer says things. The analysis and assessment of style involves examination of a writer's choice of words, his figures of speech, the devices (rhetorical and otherwise), the shape of his sentences (whether they be loose or periodic), the shape of his paragraphs- indeed, of every conceivable aspect of his language and the way in which he uses it."(Cuddon, 1999:872). Therefore, style means 'how' while content refers to 'what'. If style comes only second in priority, it certainly stands very high in importance. It is only natural that good form conveys the content in more sufficient and adequate way. On the one hand, in translation discussion, faithfulness in content has always been emphasized and treated seriously, but faithfulness in style seems to pose more difficulty. On the other hand, in literature, style allows the author to shape how the reader experiences the work. For example, one writer may use simple 
words and straightforward sentences, while another may use difficult vocabulary and elaborate sentence structures. Even if the themes of both works are similar, the differences in the authors's styles make the experiences of reading the two works distinct. Without extensive reading the capture of the style is really a tough challenge.

2 -Some Possible Problems in Translating a Poem and the solutions:

In his Approaches to Translation, Peter Newmark indicates that the translator of poetry faces some problems such as:

1- Linguistic Problems: Related to collocation and obscured (non-standard) syntactical structures.

2- Literary or Aesthetic Problems: Related to the structure (or poetic structure), metaphorical expressions, and sound.

3- Socio-cultural Problems: Related to the words or expressions which contain culturally-bound words. (Newmark, 1986:50-116)

In a general sense, Susan Bassnett quotes André Lefevere's seven strategies for translating poetry and poetic language, which might be beneficial for translating any literary language employing poetic features. These strategies are:

(1) Phonemic translation: the imitation and reproduction of the source language sounds in the target language while at the same time producing an acceptable paraphrase of the sense.

(2) Literal Translation: the emphasis on word for word translation.

(3) Metrical Translation: reproduction of the SL meter.

(4) Prose Translation or Poetry into Prose: rendering the sense of the poem into prose.

(5) Rhymed Translation: considering both rhyme and meter, to use Lefevere's words as in rhymed translation, the translator "enters into a double bondage" of meter and rhyme.

(6) Blank Verse Translation: considering structure but not rhyme.

(7) Interpretation: changing the form of the text but retaining the substance of the source language text. (André Lefevere; qtd. by Bassnett, 1980:87)

Bassnett rejects these strategies because they have "an overemphasis of one or more elements of the poem at the expense of the whole "(Bassnett, 1980:87). She argues:

In establishing a set of methodological criteria to follow, the translator has focused on some elements at the expense of others and from this failure to consider the poem as an organic structure comes a translation that is demonstrably unbalanced.

(Bassnett, 1980:87, 88)

However, this "overemphasis" may not be a drawback because as "Popovič points out, 'the translator has the right to differ organically, to be independent', provided that independence is pursued for the sake of the original in order to reproduce it as a living work." (Bassnett, 1980:88).

There are many factors that have an influence on the process of translating poetry. On the one hand, Bassnett stresses the significance of the context of the source text saying that: 
The greatest problem when translating a text from a period remote in time is not only that the poet and his contemporaries are dead, but the significance of the poem in its context is dead too. Sometimes, as with the pastoral, for example, the genre is dead and no amount of fidelity to the original form, shape or tone will help the rebirth of a new line of communication, to use Maria Corti's terms, unless the TL system is taken into account equally.

(Bassnett, 1980:88-89, Italics are not Mine)

In this sense, the "translator will continue to produce 'new' versions of a given text, not so much to reach an ideal 'perfect translation' but because each previous version, being context bound, represents a reading accessible to the time in which it is produced, and moreover, is individualistic." (Bassnett,1980:105)

The role of the translator is very important in the process as well because "any translator must first decide what constitutes the total structure ... and then decide on what to do when translating a type of poetry which relies on a series of rules that are non-existent in the TL." (Bassnett, 1980:101). Besides,"it is the duty of the translator to translate what is there and not to 'interpret' it. The fallacy of such an argument is obvious - since every reading is an interpretation, the activities cannot be separated." (Bassnett, 1980:103). On the other hand, the reader has a great role to play as well:

The reader's manufacture of meaning is thus not so much a progress through the poem and a half-random accretion of verbal associations, as it is a seesaw scanning of the text, compelled by the very duality of the signsungrammatical as mimesis, grammatical within the significance network.

(Rifaterre, 1978:166; qtd. by Bassnett, 1980:95)

3 - The language of Shakespeare:

Shakespeare uses the power of language in order to depict the scenes of his plays, such as the imagery, different types of figurative language, diction, etc. He also uses the different forms of language such as blank verse, rhymed verse, and prose. In this sense, Enani provides a full illustration to these different forms as follows:

Blank Verse: It is an unrhymed, or only occasionally rhymed, iambic pentameter which is the most common form Shakespeare uses. It is generally used to convey material more important or noble than material presented in prose, though that is not always so. Most of the important soliloquies in Shakespeare's plays are written in blank verse, though the iambic structure is often broken with variations to the metrical pattern. The variations tend to highlight important meanings.

Rhymed Verse: As most of the verse is unrhymed, the occasional use of rhyme stands out when it occurs. It often occurs in a rhymed couplet at the end of major speeches to add a sense of weight and closure to the speech, but also to highlight key ideas, emotions and plot developments. Generally, only important characters speak in rhyme and only at important moments.

Prose: Shakespeare also uses prose in a very deliberate way, generally for characters like the gravedigger, in Hamlet, who would not naturally speak in the more 
courtly, complex style of the nobility, however these characters can be more intelligent and noble than the nobility itself. Prose is also used by characters expressing more vulgar, profane, and less elevated ideas. Interestingly, even when Hamlet speaks in prose about ignoble matters, his syntax remains highly complex and poetic, perhaps a reflection of his unflagging intelligence and philosophical cast of mind.

(Enani, 1991:31-43)

4 - The Three Approaches of Translation adopted by the Three Translators:

It is evident that each of the three translators uses one approach of translation. Jabra adopts the semantic, Awad the communicative and Enani the hermeneutic one. 4-1- The Semantic and the Communicative approaches:

These two approaches represent Newmark's main contribution to translation theory. He has presented a full explanation to these two methods by saying:

Semantic translation attempts to render, as closely as...the second language allows, the exact contextual meaning of the original...Communicative translation attempts to produce on its readers an effect as close as possible to that obtained on the readers of the original.

(Newmark, 1986:39)

It should be noted that the semantic translation is literal but may not communicate well. On the other hand, the communicative translation communicates well but may not be very precise.

4-2- The Hermeneutic approach:

According to Hirsch, "hermeneutics can and should serve as a foundational and preliminary discipline for all literary interpretation."(Hirsch, 1967; qtd. by Palmer,1969:4). Hence, the purpose is not translating only but interpretation i.e. providing other ideas or concept spring from the process of translation itself in order to reach the intended meaning. In this sense, Palmer points out that "the aim of hermeneutics is perfect communication, that is, to grasp the subject or idea of the author as he would have it grasped."(Palmer,1969:81).

5 -The Analysis:

5.1 - The Blank Verse:

Example No. 1:

Queen Gertrude:

Good Hamlet, cast thy nighted colour off,

And let thine eye look like a friend on Denmark.

Do not for ever with thy vailed lids

Seek for thy noble father in the dust:

Thou know'st 'tis common; all that lives must die,

Passing through nature to eternity. (Act I. Scene II. lines 68-73)

$$
\begin{aligned}
& \text { الملكة:اسمع يا هاملت ! اطرح عنك سو اد الليل و لون حدادكَّ } \\
& \text { و انظر نظرة وُدٍٍ لمليكك و بلادكَّكُ ! } \\
& \text { لا تبحث للأبد بأجفانٍ منكسرةٌ }
\end{aligned}
$$


(Enani, 2004:110)

(Awad, 1972:40)

(Jabra, 1960:43-44)

$$
\begin{aligned}
& \text { عن و الدك الأكرم في بعض تراب الأرضن ! } \\
& \text { تعرف كم هو مألوفت بين الناسن } \\
& \text { أن مصير الأحياء إلي موتٍٍ, مارين بجسر الدنيا لخلود الأبدية ! } \\
& \text { الدلكة:أي هاملت الكريم ! انزع عنك ثياب الحداد المظلمة }
\end{aligned}
$$

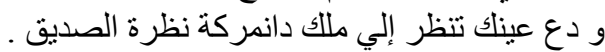

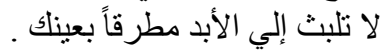

$$
\begin{aligned}
& \text { تبحث عن و الدك الثريف في أديم الثري ـ لألثر }
\end{aligned}
$$

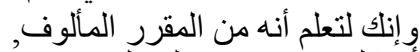

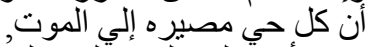

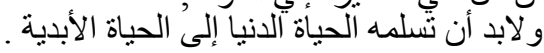

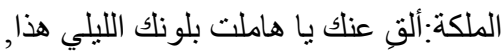

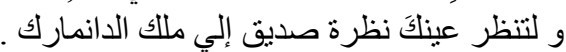

$$
\begin{aligned}
& \text { أفتبقي إلي الأبد بجفنين خفيضين }
\end{aligned}
$$

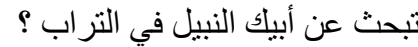

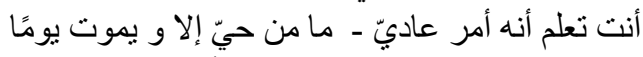

$$
\begin{aligned}
& \text { عابرًا خلال الطبيعة هذه في اتجاه الأبدية . }
\end{aligned}
$$

As shown above, Jabra has semantically translated the phrase "thy nighted colour" as " لونك الليلي هذا ", where he has rendered it literally by using the matching and equation strategy of his approach. As for Awad, he has translated the phrase as " ", "ثياب الحداد المظلمة harmony with Ramses Awad footnotes "dark mourning clothes" (Awad, nd.:36). On the other hand, Enani has translated the same phrase communicatively as " سو اد الليل و ", where he has added his own understanding to the text and kept the rhythm of the lines. Additionally, Jabra and Awad have respectively translated the

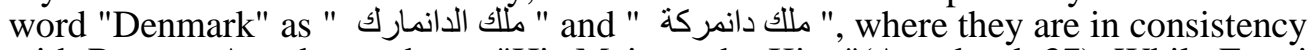
with Ramses Awad paraphrase "His Majesty the King"(Awad, nd.:37). While Enani has translated the same word hermeneutically as " مليكك و بلادكن ", where he has added the word "بلادك" in order to keep the rhyme of his lines.

By the same token, Jabra has semantically translated the word "dust" as "تراب", where he has rendered it literally by the matching and equation strategy of his approach. While Awad has translated this word communicatively as " أديم الثزري ", where he has used the substitution strategy by adding an old archaic expression. On the other hand, Enani has translated the same word hermeneutically as " بعض تراب "بعض " which means "some", in order to keep the rhythm of the line. In addition, Jabra and Enani have respectively translated the word "common" as " مألوفت " أمر عاديّ ", where they are in accordance with Ramses Awad paraphrase "frequent occurrence"(Awad, nd.:37). Awad has translated the same word communicatively as " المقرر المألوف)" ", where he has rendered it into two synonymous words, in order to give the sense of music .

Furthermore, Jabra has semantically translated the phrase "Passing through nature to eternity" as " عابرًا خلال الطبيعة هذه في اتجاه الأبدية ", where he has rendered it literally, especially the word "nature" as " الطبيعة ". This literal approach has distorted the intended meaning of the source text and therefore, the target text has become more vague to the Arabic reader. As for Awad, he has translated the phrase 
communicatively as "و لابد أن تسلمه الحياة الدنيا إلى الحياة الأبدية", where he has used the substitution strategy of his approach, especially by rendering the word "passing" into the Arabic verbal phrase "تسلهم". While Enani has translated the same phrase hermeneutically as "مارين بجسر الدنيا لخلود الأبدية", where he has used the modification strategy by providing his own Arabic figurative image, especially by adding the word "جسر "meaning "bridge". In short, Jabra and Awad do not have neither rhyme, nor rhythm, while, Enani has both. To accomplish this task, Enani has the rhythm by preserving the same number of words in each line. He has also the rhyme between

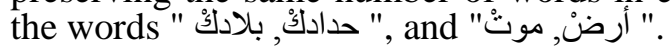

Example No. 2:

Ophelia:

I shall the effect of this good lesson keep,

As watchman to my heart. But, good my brother,

Do not, as some ungracious pastors do,

Show me the steep and thorny way to heaven;

Whiles, like a puff'd and reckless libertine,

Himself the primrose path of dalliance treads,

And recks not his own rede.

(Act I. Scene III. lines 45-51)

(Enani, 2004:124)

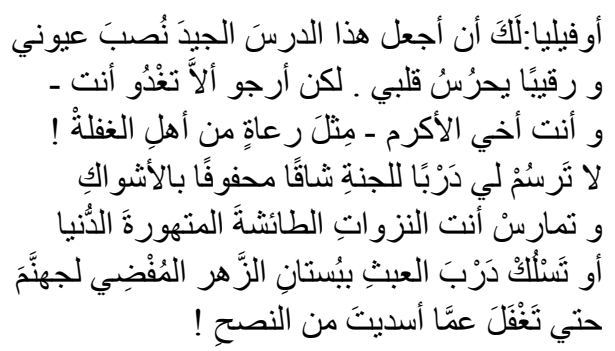

(Awad, 1972:52)

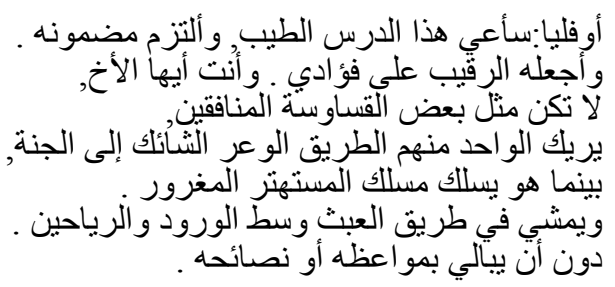

$$
\begin{aligned}
& \text { أوفيليا:سأجعل مضمون هذا الدرس المفيد }
\end{aligned}
$$

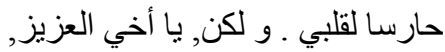

$$
\begin{aligned}
& \text { لا تفعل كما يفعل كاهن للئي, } \\
& \text { يريني الطريق الكأداء الثائكة إلي السماء لاء }
\end{aligned}
$$

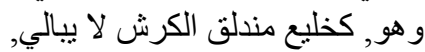

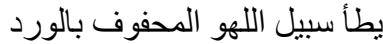

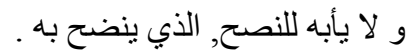

(Jabra, 1960:58)

As seen above, the three translators have succeeded, each in his own way, to preserve the intended meaning. Jabra has translated these lines semantically, where 
he has rendered them literally by using the matching and equation strategy. Jabra has literally rendered the word "heaven" as " السماء ", where he has distorted the intended meaning of the source text. Awad and Enani have translated it suitably as " الجنة ", where they are in accordance with Ramses Awad paraphrase "eternal bliss"(Awad, nd.:57). Additionally, Jabra has rendered the phrase " for the phrase "the steep and thorny way", and the phrase " كخليع مندلق الكرش " for the phrase "like a puff'd and reckless libertine", where he has added uncommon and out-of-date " الورود و الرياحين " Arabic phrases. On the other hand, Awad has translated the phrase " for the word "primrose", and the phrase " بمو اعظه أو نصائحه " for the word "rede", where he has rendered these words in a synonymous structure in order to reveal a kind of music. Moreover, Enani has translated the lines hermeneutically by using the modification strategy, in order to demonstrate his own point of view and analysis to the text. He has added the words " الدنيا , بستان " and the phrase "المفي لجنم ", which have no references in the source text, for the sake of making the text more intelligible, on the one hand, and keeping the rhyme, on the other one. Therefore, Enani is the most successful in striking balance between form and content by maintaining both, the rhythm and rhyme throughout his lines. For instance, the word

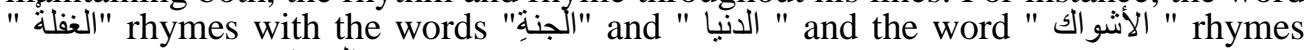
with the word " النزوات ".

Example No. 3:

Ghost:

I find thee apt;

And duller shouldst thou be than the fat weed

That roots itself in ease on Lethe wharf,

Wouldst thou not stir in this. Now, Hamlet, hear:

'Tis given out that, sleeping in my orchard,

A serpent stung me; so the whole ear of Denmark

Is by a forged process of my death

Rankly abused: but know, thou noble youth,

The serpent that did sting thy father's life

Now wears his crown.

(Act I. Scene V. lines 32-39)

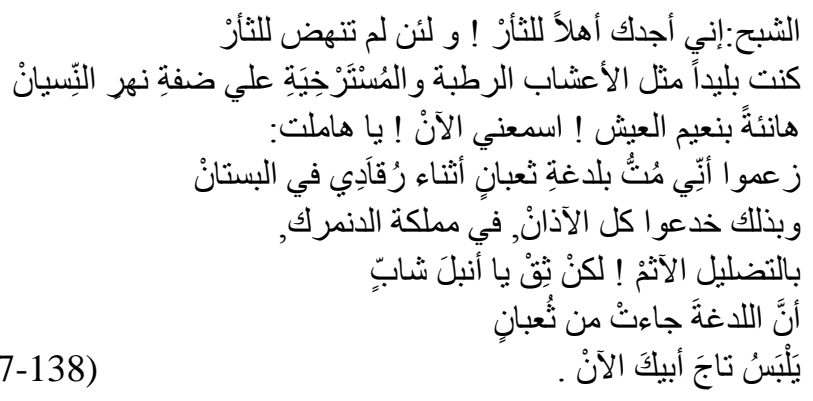

(Enani, 2004:137-138)

$$
\begin{aligned}
& \text { الثبح:أر اك علي تمام الأهبة . }
\end{aligned}
$$

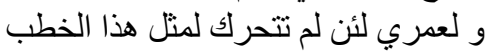

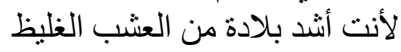

$$
\begin{aligned}
& \text { الذي يسري فيه العفن علي شاطئ نهر ليثي الغني }
\end{aligned}
$$


(Awad, 1972:62-63)

$$
\begin{aligned}
& \text { و الآن أنصت إليَّ يا هملت . } \\
& \text { لقد أذاعو ا أنه لذعني ثعبان و أنا راقد في البستان, } \\
& \text { و و هكذا خدع سكان دانمركة جميعاً. }
\end{aligned}
$$

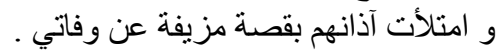

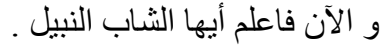

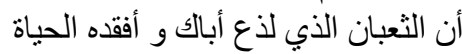

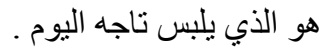

$$
\begin{aligned}
& \text { الطيف:أر الك متهيئًا للعمل, }
\end{aligned}
$$

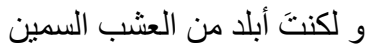

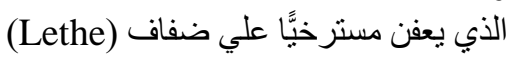

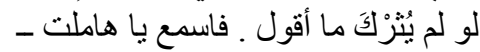

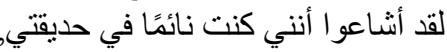

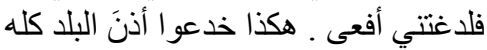

$$
\begin{aligned}
& \text { بالتلفيق عن موني ـ و لكن اعلم العم أيها الفني النبيل, } \\
& \text { أن الأفعى التي لدغت الحياة من أبيك الديك }
\end{aligned}
$$

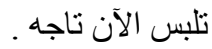

(Jabra, 1960:71)

As the quotations show, Jabra and Awad have respectively translated the sentence "I find thee apt" as "أر أر متهينًا للعمل " and " أر على تمام الأهبة ", where they are in accordance with Ramses Awad paraphrase "I am glad you are so ready" (Awad, nd.:77). Enani has translated the same sentence hermeneutically as " إني أجدك" !"أهلاً للثأز !", where he has put forward his own explanation to the text by using the modification strategy especially by rendering the phrase " أهلا للثأر "apt".

In addition, Jabra has translated the word "Lethe" as it is, or to be specific, he has not translated it at all. Awad has translated the word communicatively as "نهر ليثي where he has used the transliteration strategy. On the other hand, Enani has translated the word hermeneutically as " نهر النَّنبانْ ", where he has used the modification strategy by taking into consideration the ancient myth connotations regarding this River. Enani's is in concordance with Ramses Awad paraphrase "the River of Forgetfulness" (Awad, nd.:77). Furthermore, it should be noted that both Jabra and Awad have proffered an explanation footnote concerning the word "Lethe". On the one hand, Jabra has indicated that: "'Lethe' is the river of forgetfulness in the lower world" (Jabra, 1960:71). On the other one, Awad has added that "in the Greek legends, Lethe is a river in the lower world, where the souls of dead drink of and forget all they have faced in their lives" (Jabra, 1960:63; Translation Mine).

Likewise, Jabra has semantically translated the phrase "The serpent that did sting thy father's life" as " الأفعى التي لدغت الحياة من أبيك ", where he has rendered it literally by the matching and equation strategy. While Awad has translated the phrase communicatively as " الثعبان الذي لذع اباك و أفقده الحياة ", where he has rendered it conveniently to this context. On the other hand, Enani has translated the same phrase hermeneutically as " اللدغة جاءتْ من نعبانٍ ", where he has used the modification strategy by passing over the translation of the phrase "thy father's life", concerning it inclusively understood from the context. In short, Jabra has translated these lines 
semantically where he has distorted the images of Shakespeare owing to the literalness of his approach. Awad has translated the lines communicatively where he has given his own understanding to the text in order to trace the meaning with a great deal of interest to keep a sort of music by adding some expressions such as " " لعمري " and using the transliteration strategy. As for Enani, he has translated the lines hermeneutically by modifying the lines to attain the intended meaning especially by adding phrases that reveal the original images, such as " هانئةً بنعيم العيش " which has no reference in the source text though.

Due to this, Jabra has lost both, the rhythm and rhyme because of the literalness of his approach. While Awad has lost them too but he has tried to keep the sense of music by adding his poetic expressions. By contrast, Enani has kept both, the rhythm and rhyme, and to achieve this purpose, he has provided rhyming words, such as: "

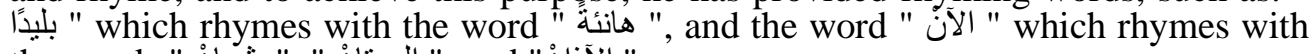
the words " ثنعبان ", "البنتان ", الآذانْ ".

\section{2 - The Rhymed Verse:}

The ensuing part of the paper will show, through examples from the translations under study, how each of the three translators handled the problem of transferring rhymed verse.

Example No. 4:

Hamlet:

A whole one, I.

For thou dost know, O Damon dear,

This realm dismantled was

Of Jove himself; and now reigns here

A very, very - pajock.

Horatio :

You might have rhymed.

(Act III. Scene II. lines 266-271)

(Enani, 2004:222-223)

$$
\begin{aligned}
& \text { هاملت :فهل علمت يا دامون ؟ با أيها الر اعي الأمين } \\
& \text { بأن هذي الدولة التي بنا تنهار }
\end{aligned}
$$

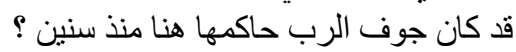

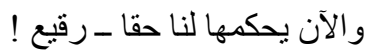

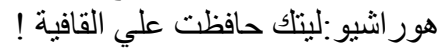

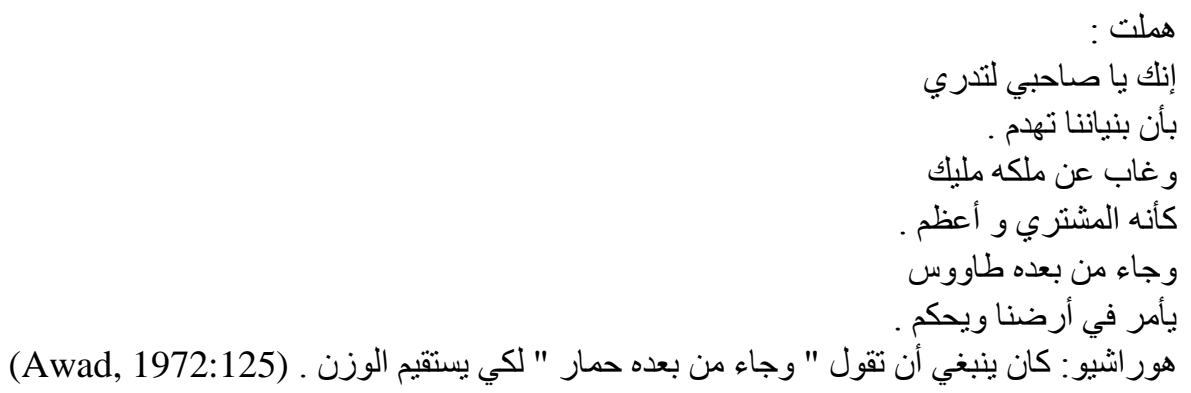


(Jabra, 1960:151)

$$
\begin{aligned}
& \text { ليَ سهُمْ كامل أنا ـ (يغني) } \\
& \text { يا عزيز القلب تدري أنتا } \\
& \text { قد سُلبنا ربَّنا } \\
& \text { وغدا يحكنا في أرضنا } \\
& \text { طاوس زنيج ؟ } \\
& \text { هور اثشيو :ليتك ققيت ! }
\end{aligned}
$$

In this passage, Jabra and Enani have translated these lines suitably to the context concerning the form and content. They have respectively translated the word "pajock" as " زقنيع " رقني ", where they have altered the rhyme of their lines in order to preserve the intended meaning of this context. By contrast, Awad has kept the rhyme in his lines without taking into account the context of the source text. Besides, he has translated communicatively the sentence "You might have rhymed" as " كان ينبغي أن تقول " وجاء من بعده حمار " لكي يستقيم الوزن ", where he has provided unneeded additions that affect badly the economy of the verse language. Nevertheless, Jabra and Enani have adhered to the original context by translating

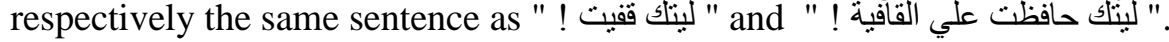

\section{Example No. 5:}

First Clown: [Sings]

But age, with his stealing steps,

Hath claw'd me in his clutch,

And hath shipped me intil the land,

As if I had never been such.

(Act V. Scene I. lines 67-70)

(Enani, 2004:296)

$$
\begin{aligned}
& \text { الحفار :(بغني) }
\end{aligned}
$$

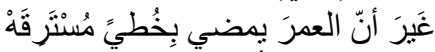

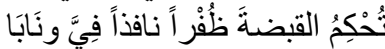

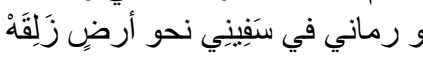

$$
\begin{aligned}
& \text { فكأنّي لم أكن يومًا شبابًَا ! } \\
& \text { الفلاح الأول:(بغني) } \\
& \text { آه للاهر الذي أفني شبابي } \\
& \text { وسقاني كار هاً مر شر ابتي } \\
& \text { وبظفر غالني منه وناب } \\
& \text { كاني لم أكن زين صحابي } \\
& \text { المهرج الأول:(يغني و هو يحفر) - } \\
& \text { راح يومي يا إلهي }
\end{aligned}
$$

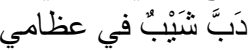

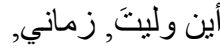

$$
\begin{aligned}
& \text { بشبابي و هيامي }
\end{aligned}
$$

(Awad, 1972:183)

(Jabra, 1960:221) 
As the translations show, Jabra has translated the lines unsuitably to the intended meaning by presenting a translation from his own view. There are not any references to these lines in the source text. It is evident that Jabra has done so in order to trace the sense of music. He has added the rhymed phrases " هيامي ,زماني , عظامي , إلهي ". As for Awad, he somehow has not adhered to the intended meaning of the source text owing to the substitution strategy of his communicative approach. He has passed over the translation of the phrase "with his stealing steps" and the line "And hath shipped me intil the land". Besides, Awad has added a phrase and a line of his own which have no references in the source text: "وسقاني كار ها مر شر ابي" and "الذي أفني شبابي ". He has kept the rhyme by the rhyming phrases " صحابي رشر ابي رشبابي" ". On the other hand, Enani has translated these lines hermeneutically as usual by the modification strategy. He has translated the phrase "with his stealing steps" as " بخطي مُسنتَرِقََْْه ", where he has added his own analysis and clarification to the text, which is in consistency with Ramses Awad paraphrase "stealthy approach" (Awad, nd.:323). In

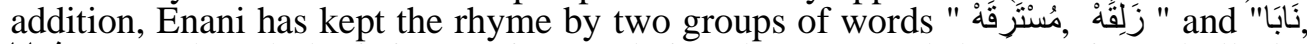
شبابا ". On the whole, it is Enani's translation that captured the meaning wholly by retaining both the form and content.

Example No. 6:

Hamlet:

Imperious Caesar, dead and turn'd to clay,

Might stop a hole to keep the wind away:

$\mathrm{O}$, that that earth, which kept the world in awe,

Should patch a wall to expel the winter flaw! (Act v. Scene I. lines 198-201)

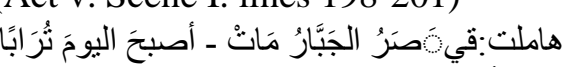

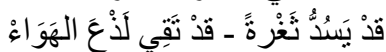

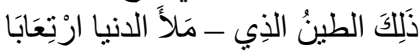

(Enani, 2004:304)

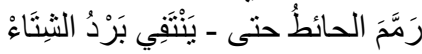

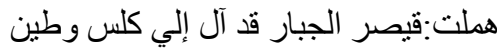

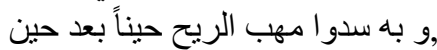

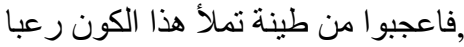

(Awad, 1972:189)

صار ثقب الدار مثو اها علي مر السنين .

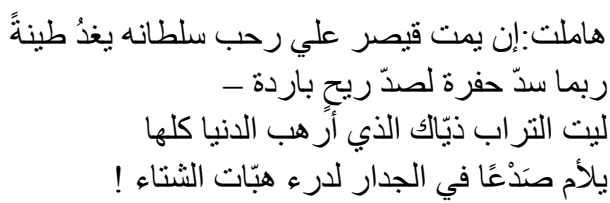

(Jabra, 1960:229)

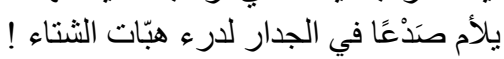

In the above extracts, Jabra has translated these lines as usual by adding his poetic expressions such as " ليتّات الثتاء " and ", in order to provide the sense of music to the readers. Besides, he has lost both, the rhythm by avoiding the use of one measure and the rhyme by adding unrhymed words to his lines " طينة , ". While Awad has adhered to his substitution strategy of the 
communicative approach by adding the additive synonymous phrase " كلس وطين as a translation for the word "clay". Also, he has added some phrases which have no references in the source text such as: "حينا بعد حين " and " مثواها علي مر السنين ". These additions are intended for the sake of stirring the souls of the readers caused by the sense of music. Besides, Awad has passed over the translation of the phrase "to expel the winter flaw". Yet, he has kept both the rhythm throughout his lines and the rhyme by the rhymed words " السنين ,حين ,طين . On the other hand, Enani has translated these lines suitably to their Arabic equivalent. He has kept the rhythm by scanning all the lines in the same measure. Besides, Enani has preserved the rhyme by the use of two groups of rhymed words " الشتاء, الهواء " and " ارتعبا , ترابا ". Accordingly, it is obvious that Enani's translation has captured wholly the intended meaning of the source text.

\section{Conclusion}

This paper has practically evaluated the translations of Hamlet by Jabra Ibrahim Jabra, Mohammed Awad Mohammed, and Mohammed Mohammed Enani with regard to the language of verse. It has been found that Jabra, Awad, and Enani have insisted on transferring verse by their very approaches. Jabra has been found translating verse into verse by using the matching and equation strategy in claim of faithfulness. Jabra sacrifices major formal characteristics of poetry; i.e. the rhyme scheme and meter. He sometimes tries to make up for the loss of sounds and sound effects by choosing suitable Arabic words and sounds. Jabra does not have meter and does not rhyme wherever rhyme is available. Even when he tries to translate line by line, the Arabic version is not metered. Metrical and rhymed translation is nothing an easy task. What Jabra comes up with is blank verse that does not follow a meter or a rhyme.

On the other hand, Awad has translated verse into verse, except the rhymed verse by using the substitution strategy in order to keep the music, even without keeping the intended meaning. He has added many and many synonymous phrases to provide shades of music on his Arabic version. Both Jabra and Awad have been found taking an interest in the form not in the content. As for Enani, he has translated verse into prose, except the rhymed verse, using the modification strategy in order to keep the intended meaning of the source text. He has used variable Arabic measures in order to suit the English rhyme and rhythm and to be in accordance with the different dramatic purposes of the context. The reason of Enani's variety in measures is that sounds have meanings and they contribute to the overall meaning of the text.

Accordingly, it has been found that the semantic approach suits the purpose of translation in some occasions but in others it fails totally due to the literal meaning it produces. On the other hand, the communicative approach has been found seeking the form at the cost of the content which leads to failure to reach the intended meaning. Eventually, the hermeneutic approach has been found the suitable choice to trace the meaning either in form or in content. 


\section{Works Cited}

1. Awad, Ramses, ed.. William Shakespeare, Hamlet. Cairo: The AngloEgyptian

2. Bookshop, n.d. print.

3. Bassnet, Susan. Translation Studies. London : Methuen, 1980. Print.

4. Cuddon, J. A. The Penguin Dictionary of Literary Terms and Literary Theory.

5. London: Penguin books, 1999. Print.

6. Jeffares, A. N., ed. . William Shakespeare, Hamlet. Beirut: York Press, 1992. Print.

7. Newmark, Peter. Approaches to Translation. Oxford: Pergamon Press, 1986. Print.

8. Palmer, Richard. Hermeneutics. USA: Northwestern University Press, 1969. Print.

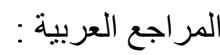

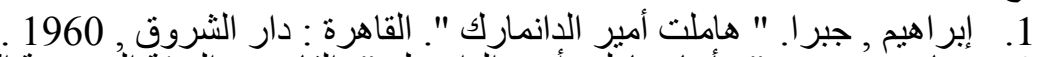

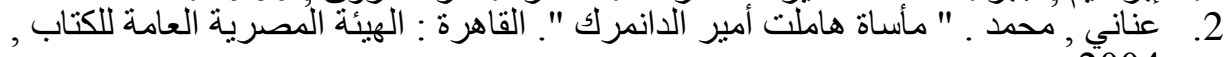

$$
\begin{aligned}
& \text {. } 2004 \\
& \text { 3. عناني , محمد . " يوليوس قيصر ". القاهرة : الهيئة المصرية العامة للكتاب , } 1941 .
\end{aligned}
$$

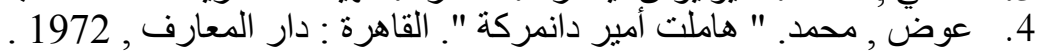

